\title{
SPINAL DEFORMITIES WITH PARAPLEGIA IN TWO SISTERS WITH MORQUIO-BRAILSFORD SYNDROME
}

\author{
By J. Melzak, M.D. \\ National Spinal Injuries Centre, Stoke Mandeville Hospital
}

ACCORDING to Zellweger et al. (1952), among the constitutional disturbances of bone growth one must distinguish between disturbances visible at birth, depending on impairment of cartilaginous growth, such as achondroplasia and dyschondroplasia and the progressive disturbances appearing after birth in which the enchondral ossification is primarily impaired. In the latter group the children are usually born after a normal pregnancy and their development is in the beginning normal. The first changes usually appear soon after the child starts to walk when deformities of the bones of spine and extremities can be seen. Further dwarfism, short neck and short trunk, develops while the length of extremities is being less affected. The syndrome is in some cases complicated by paraplegia.

This syndrome was described by L. Morquio from Montevideo in March 1929 in the Bull. Soc. Pediat. de Paris under the title 'Sur une forme de dystrophie osseuse familiale'. The same syndrome was described in June of the same year by J. F. Brailsford from Birmingham, England, as 'Chondro-osteodystrophy, roentgenographic and clinical features of child with dislocation of vertebrae' in the Am. F. Surg. (1929), 7, 404-IO. Dr. J. F. Brailsford actually presented the same case in 1928 at a meeting of the Royal Society of Medicine.

\section{CASE RECORDS}

The children, A. U. aged I6 and F. U. aged I4, were born from not related parents. F. U. is one of twins, the other twin having a hare lip. F. U. was admitted on Io May I 968 to the National Spinal Injuries Centre from the Children's Hospital, Birkenhead, where she was under Mr. T. Evans. A. U. was treated here as out-patient. A brother aged 4 seems at present normal. There was after the first pregnancy a still-born child. The father, aged now 48, is a healthy man of a height of $5 \mathrm{ft} .9 \frac{1}{2}$ in. and weighs $12 \mathrm{st} 8 \mathrm{lb}$. His father was English and mother Irish. Never seriously ill before, no venereal diseases. During the Second World War was for $3 \frac{1}{2}$ years a prisoner-of-war in Japan. Is employed as teacher in a Technical College. The mother also a healthy woman aged 44, height $5 \mathrm{ft}$. and weight $8 \mathrm{st} .8 \mathrm{lb}$., and was never seriously ill. Her father was English and mother Scottish. During her first pregnancy she developed hypertension and kidney trouble. The child was born at the age of 7 months, still-born. It was a girl.

A. U., aged I6, was born after normal pregnancy and confinement and at the age of 3 months mother noticed a lump on the spine (fig. I). Started to walk when I 8 months old. Teeth and speech normal time. At the age of Io started to feel unsafe when walking and paraparesis was diagnosed. Was wearing a plaster corset. Is able to walk now using long calipers on the left leg, supported on two sticks. Is now a boarder at Stitchery School.

A. U. has a round head, skull circumference 22 inches, short saddle nose with dilated nostrils. Broad mouth, pouting lips, prominent maxilla, widely spaced teeth, characteristic gargoyle-like face. Tongue flat, large. Very short neck. Loose joints in fingers and wrists (hyperextensible). Barrel chest with kyphoscoliosis. Good general condition. Height $4 \mathrm{ft}$. Length of upper and lower limbs 25 in. 
Cardiovascular System. B.P. II0/70. Pulse 82 minute, regular. Systolic and faint diastolic murmur over the heart, best heard over aorta.

Respiratory System. Noisy respirations; slight, frequent cough.

Alimentary System. Nil abnormal. No enlargements of spleen or liver.

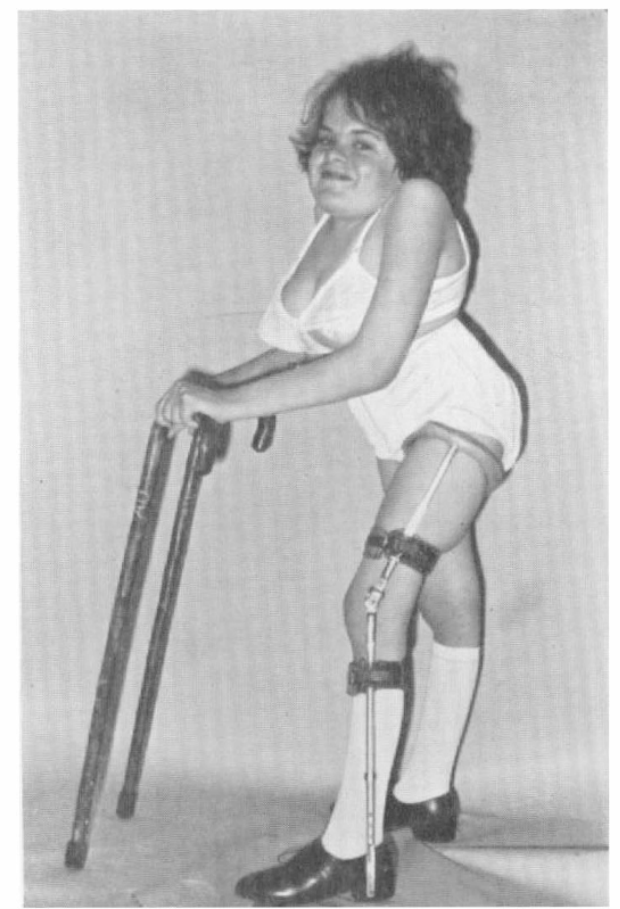

FIG. I

A. U. aged 16 , height $=4 \mathrm{ft}$.

Morquio-Brailsford syndrome.

\section{Central Nervous System}

Cranial Nerves. Good eyesight, corneal haziness visible. Fundi normal. Mentally orientated in place and time, but not interested in general problems. Can read fluently but does not really understand the text. In spite of being almost 17 years old, has a personality of a child of IO: uncertainty, easily gets upset and cries. At Stitchery School makes progress.

Motor Power. All muscles in the upper limbs had full power, intercostal and abdominal muscles contract voluntarily. In the lower limbs weakness in muscles, especially hamstrings, causing hyperextension of knees, more on the left. Walks using a long caliper on the left leg, supported on two sticks about 20 yards.

Reflexes. Positive and symmetric in upper limbs. Spastic finger flexion reflex negative. Abdominal reflexes negative. Knee and ankle jerks positive. Babinski and Rossolimo positive bilaterally. All modalities of sensation were present throughout.

Bladder Function. Was normal, except that is unable to hold urine for long and is passing urine on laughing.

Bowels. Open daily.

Started menstruations at the age of 13 , menstruations regular. 
Investigations. Hb. IO2 per cent. Blood urea $33 \mathrm{mg}$. per cent., white count 7500 . Glucose fasting I $40 \mathrm{mg}$. per cent. $\mathrm{Na}=\mathrm{I} 34 \mathrm{mEq}$./1.; Ka= $4.5 \mathrm{mEq}$./1.; $\mathrm{Cl}=96 \mathrm{mEq}$./1.; Bicarb $=30 \mathrm{mEq} . / 1$. Blood group $=\mathrm{A} ;$ Rhesus $=$ positive. Metachromatic granulations in polymorph leukocytes present (Reilley, I94I). (Dr. med. C. S. Pitcher.) W.R.= negative. P.P.R. = negative.

Urine sterile.

Screening test for mucopolysaccharides (cetyl-trimethyl-ammonium bromide) $=$ strongly positive (Meyer, I957). (Dr. phil. L. C. A. Nunn.)

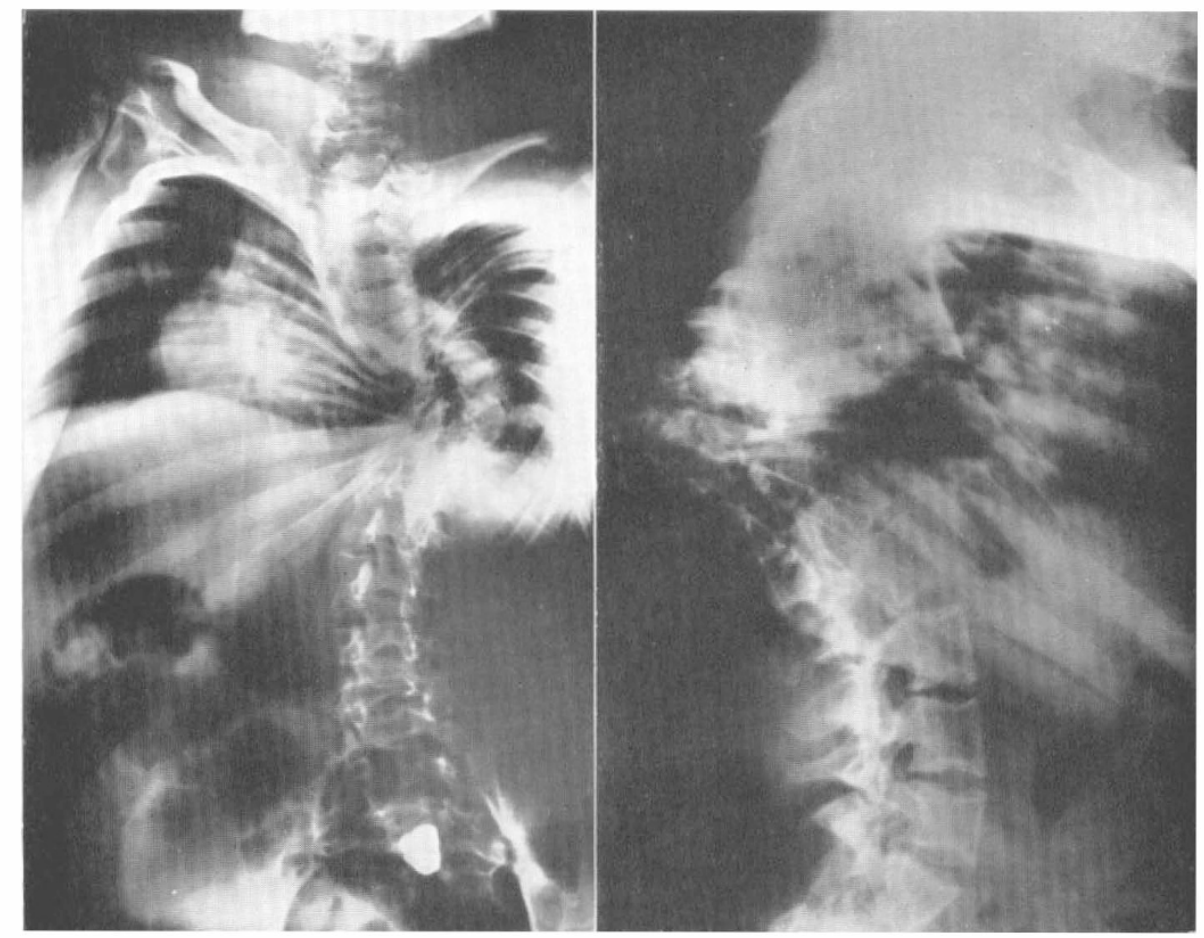

FIG. 2

A. U. Kyphoscoliosis. Irregular vertebral bodies. Spina bifida $\mathrm{S}_{2}-\mathrm{S}_{3}$.

$X$-ray of bones

I. Skull-no lession detected.

2. Spine-marked congenital anomalies, irregular vertebral bodies. Spina fibida occulta S2-3. Kyphoscoliosis. Short trunk and neck (fig. 2).

3. Thorax-gross deformity of the thoracic cage. Gibbus deformity at lower dorsal level. Defects in ribs especially right which are oar shaped (fig. 3).

4. Both hip joints-subluxation of the left. The base of the pelvis and femur show some underdevelopment.

5. Both knees and tibia-the epiphyses are united in both knee joints and ankles. Full growth of tibia.

6. Both forearms-deformities of lower ends of radius and ulna.

Summarising, this child aged I6 has: (I) severe bony changes, short neck, kyphoscoliosis and dwarfism with characteristic gargoyle-like face, comparatively long extrem- 
ities; (2) cloudy corneae; (3) retarded intellect; (4) metachromatic granulations in polymorph leukocytes; (5) heart changes; (6) incomplete paraplegia below Tı2; (7) positive test for presence of excessive amounts of mucopolysaccharides.

These symptoms are compatible with the Morquio-Brailsford syndrome.

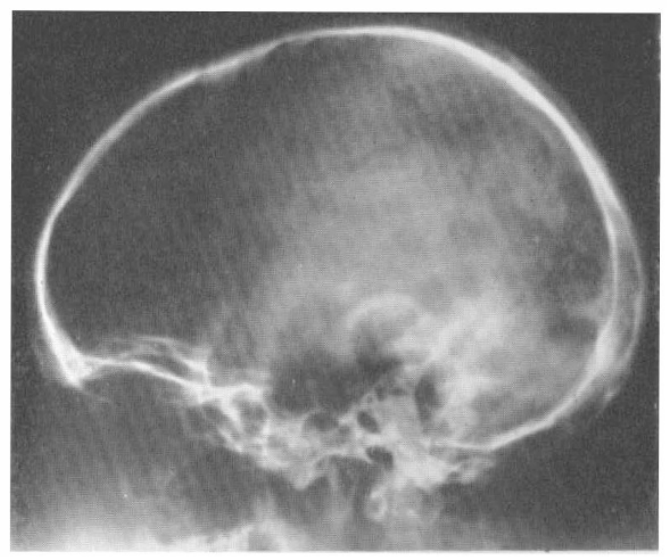

FIG. 3

A. U. Deformed thoracic cage. Oar-shaped ribs. Subluxation in left hip joint. Under-developed pelvis and femurs.

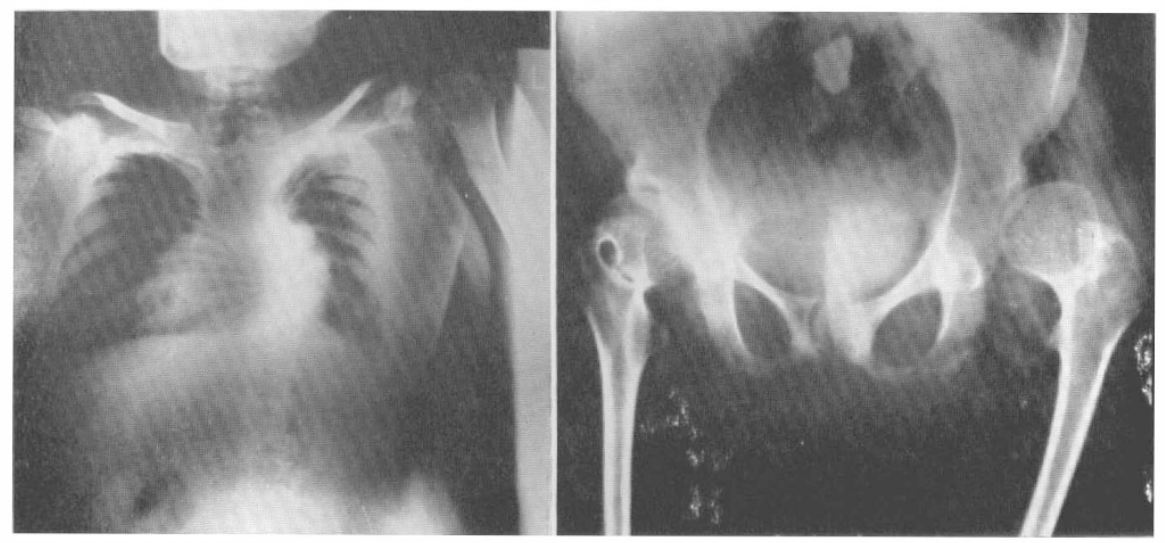

F. U. was born half an hour after her twin sister S., who has a hare lip but is otherwise perfectly healthy, well developed mentally and physically (fig. 4). F. was born after normal pregnancy of 9 months. No forceps were used. At birth it was noticed that her: feet were turned inwards. This was corrected with plasters and the feet were straight at the age of 2. It was soon noticed that F. is pigeon-chested.

At the age of 9 she developed epilepsy. Had electro-encephalogram. Was taking Phenobarbitone $\frac{1}{2}$ a grain twice a day and has not had an epileptic fit for the last three years. Had, however, recently a fit and Epanutin had to be added to control the fits. Always had a short body and long legs. Was always shorter than her twin sister but is taller by 5 in. than her elder sister who also has Morquio-Brailsford syndrome. At the age of I I, changes in the heart were noticed. In April I 968 could walk normally. Started to fall in May I968. F. has a round head, circumference of skull $21 \frac{1}{2}$ in. Hair thick, dry. Eyes placed wide apart. Short saddle nose with dilated nostrils. Broad mouth, pouting lips, prominent maxilla, widely spaced greyish teeth, thinness of enamel which is fractured in places (notching). Tongue flat, large. Hoarse voice. Very short neck. Very loose 
joints in fingers and wrists (hyperextensible). Barrel chest with kyphoscoliosis. Protruding large navel. No inguinal hernia. Small amount of hair in arm pits and on mons pubis. General condition good.

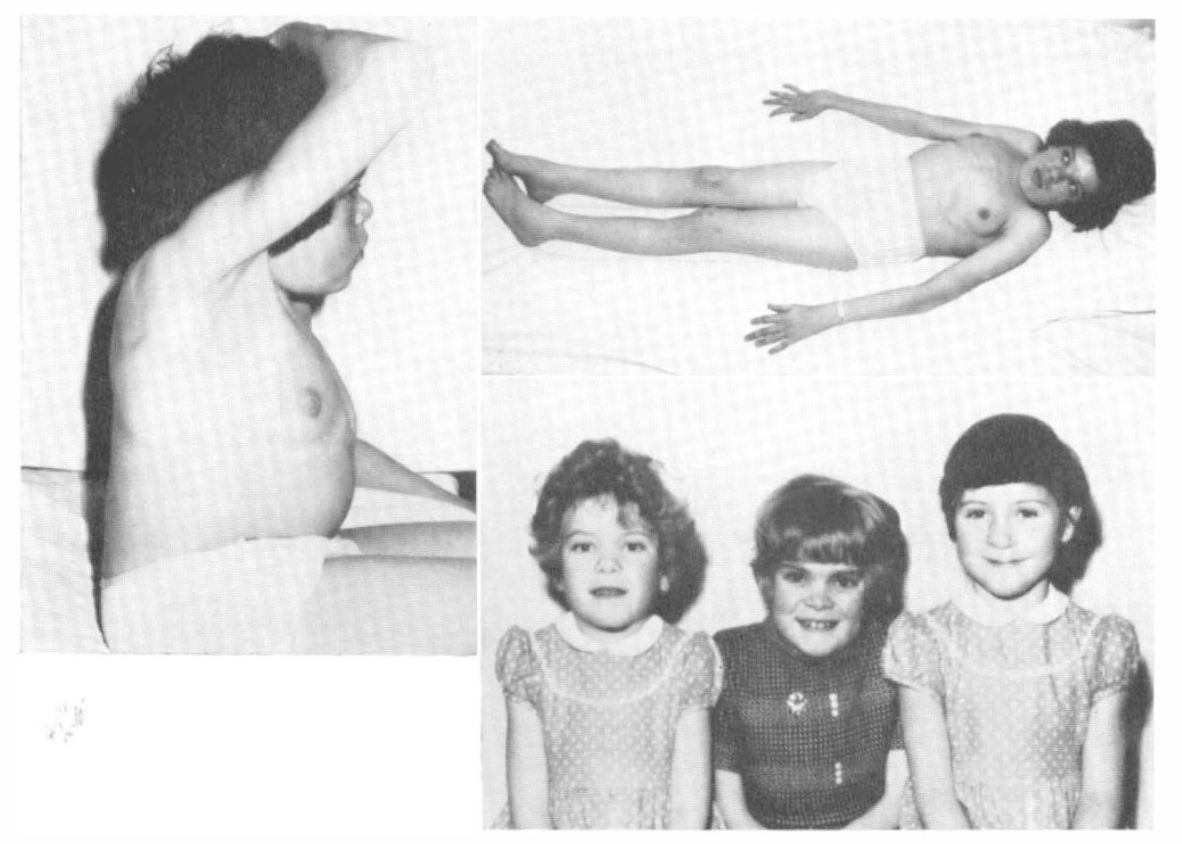

FIG. 4

Left and top: F. U. aged I4, height $=4 \mathrm{ft} .5$ in., Morquio-Brailsford syndrome.

Bottom right: The twins F. U. and S. U. aged 4 and A. U. aged 6 in the middle.

Cardiovascular System. Blood pressure 106/70 mm. Hg. Pulse 95 per minute, regular. Over the heart, loud systolic and quiet short diastolic murmur best heard over the aorta, splitting of the second sound. Nil abnormal in the respiratory system. Good appetite, no indigestion. Liver not enlarged, spleen not enlarged.

\section{Central Nervous System}

Cranial Nerves. Good eyesight, fundi normal, corneal haziness due to deposits of granulations in the cornea seen through slit-lamp (Mr. J. Moss, F.R.C.S.). Hearing diminished in the left ear. Mentally well orientated in time, place and persons. Knows letters but can read with difficulty only short words. Her reading age is that of a child of 7 . She knows figures but can only calculate correctly up to 5. Was developing mentally normally as her twin sister up to the age of 10 when her mental development became slow. Emotionally quiet, composed, sensible. Attends hospital school, making slow progress.

Motor power. All muscles in the upper limbs had full power, intercostal and abdominal muscles were present, lower abdominals being weaker. In the lower limbs, complete paralysis except some little power in adductors, quadriceps, right hamstrings.

Reflexes. Were normal in the upper limbs; abdominal reflexes absent except left upper and middle which are positive. Knee jerk positive on right, exaggerated on left, ankle jerks positive, Babinski and Oppenheim positive. 
Sensation. To light touch there was hypoaesthesia below TI2. She felt pinprick throughout, joint sensation was grossly impaired in toes, vibration sense absent below TI2 on right and L2 on left. Figure writing was unable to discriminate below Tio.
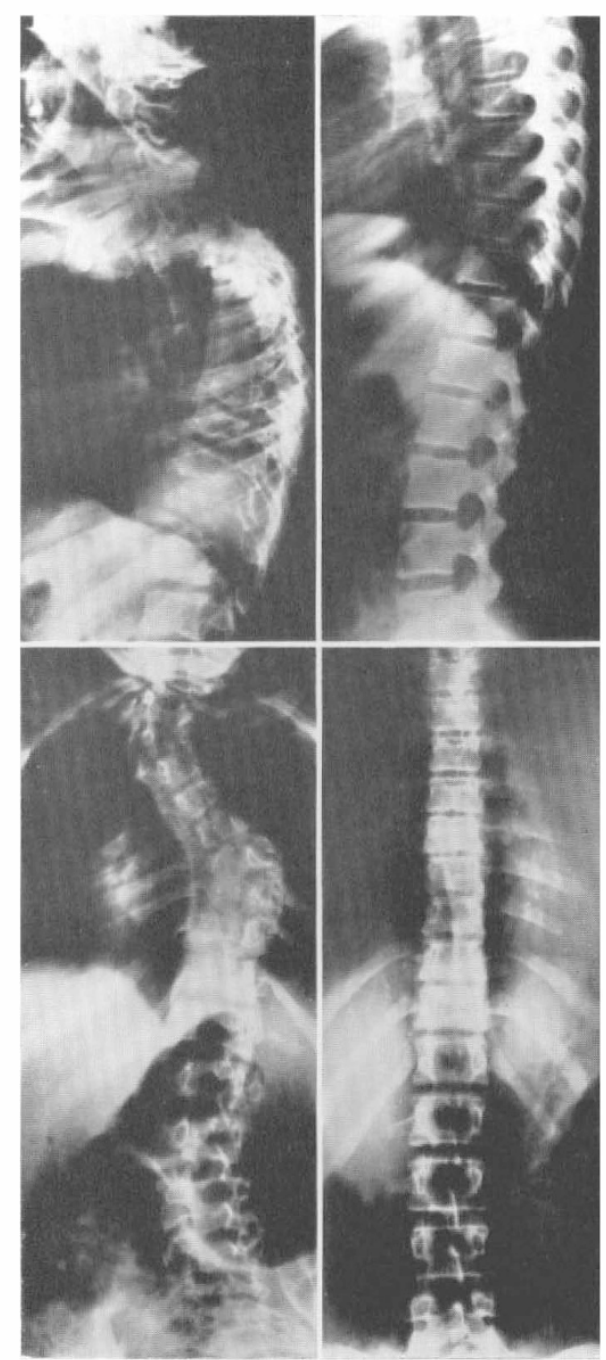

FIG. 5

The spines of the twins. F. U. has kyphoscoliosis. Anomalies in vertebral bodies. Spina bifida. Normal spine by S. U.

Bladder function was normal with good sensation of fullness and when passing urine. Does not get wet. Bowels function also normal with good sensation of fullness and when having bowels open which she does daily on the toilet.

Menstruations. Started her first period a month ago. 
Investigations. Electrocardiogram normal with sinus arrythmia. Hb I I 3 per cent., white count 7000, presence of metachromatic granulations in leukocytes. Blood urea $35 \mathrm{mg}$. per cent. Glucose fasting I IO mg. per cent. Blood group $\mathrm{A}_{1}$. Rhesus=negative. W.R.= negative. P.P.R. = negative.

Urine sterile.

Urine screening test for mucopolysacchariduria positive (cetab $=$ cetyltimethylammonium bromide (Mayer).

\section{$X$-ray of bones}

I. Skull-normal, sella turcica normal.

2. Spine-marked anomalies in cervical, dorsal, lumbar, sacral and coccygeal vertebrae (fig. 5). Vertebral bodies irregular in shape; flat vertebrae, kypho-scoliosis in dorso-lumbar spine, lateral dislocation $\mathrm{T}_{9}$ to $\mathrm{T}_{\text {Io }}$ vertebrae, spina bifida occulta $\mathrm{S}_{\mathrm{I}}$, large flat coccyx.

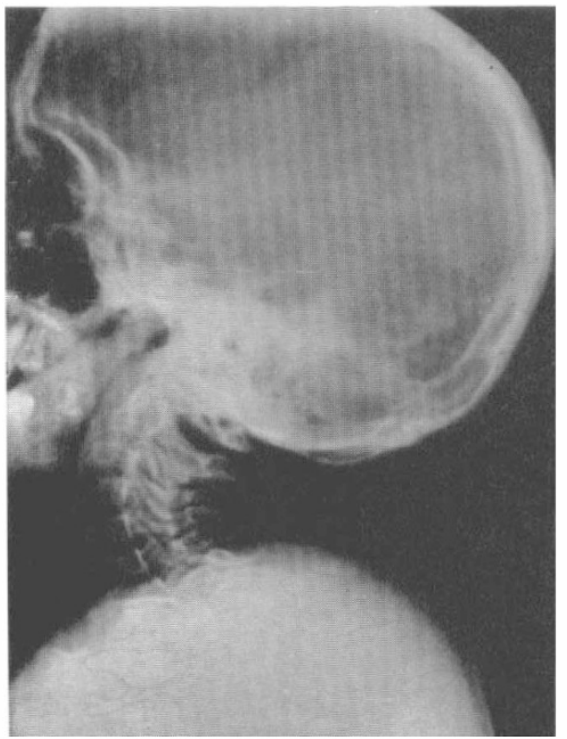

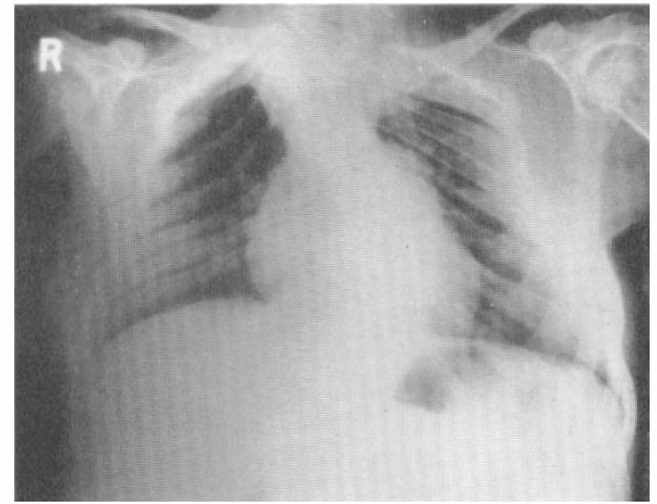

FIG. 6

F. U. Deformed thoracic cage, oar-shaped ribs.

3. Thorax-deformity of thoracic cage, kyphosis, oar-shaped ribs (fig. 6). Anomalies in carpal bones and lower end of radii. Deformed shape of radius and ulna (fig. 7).

Infantile type of pelvis with shortening of the femoral neck. Irregularities and exostoses in metatarsal bones.

Summarising, this child, aged I4, has: (I) severe bony changes, short neck, kyphoscoliosis and dwarfism with characteristic gargoyle-like face, comparatively long extremities; (2) cloudy corneae; (3) retarded intellect; (4) severe heart changes; (5) metachromatic granulations in polymorph leukocytes; (6) incomplete paraplegia below TıO; (7) positive test for presence of excessive amounts of mucopolysaccharides.

These symptoms are compatible with the Morquio-Brailsford syndrome. As this patient F. U. has a twin sister, S. U., who apart from having a hare-lip is developed normally from the physical and mental point of view, we had the unique opportunity to compare the findings (fig. 8). S. U. is taller by 6 in. and she is I stone $4 \mathrm{lb}$. heavier. She has normal bones, no changes in the spine and her face has normal features. She has no 
corneal clouding, no metachromatic granules in the leukocytes and the screening test for mucopolysaccharides was negative.
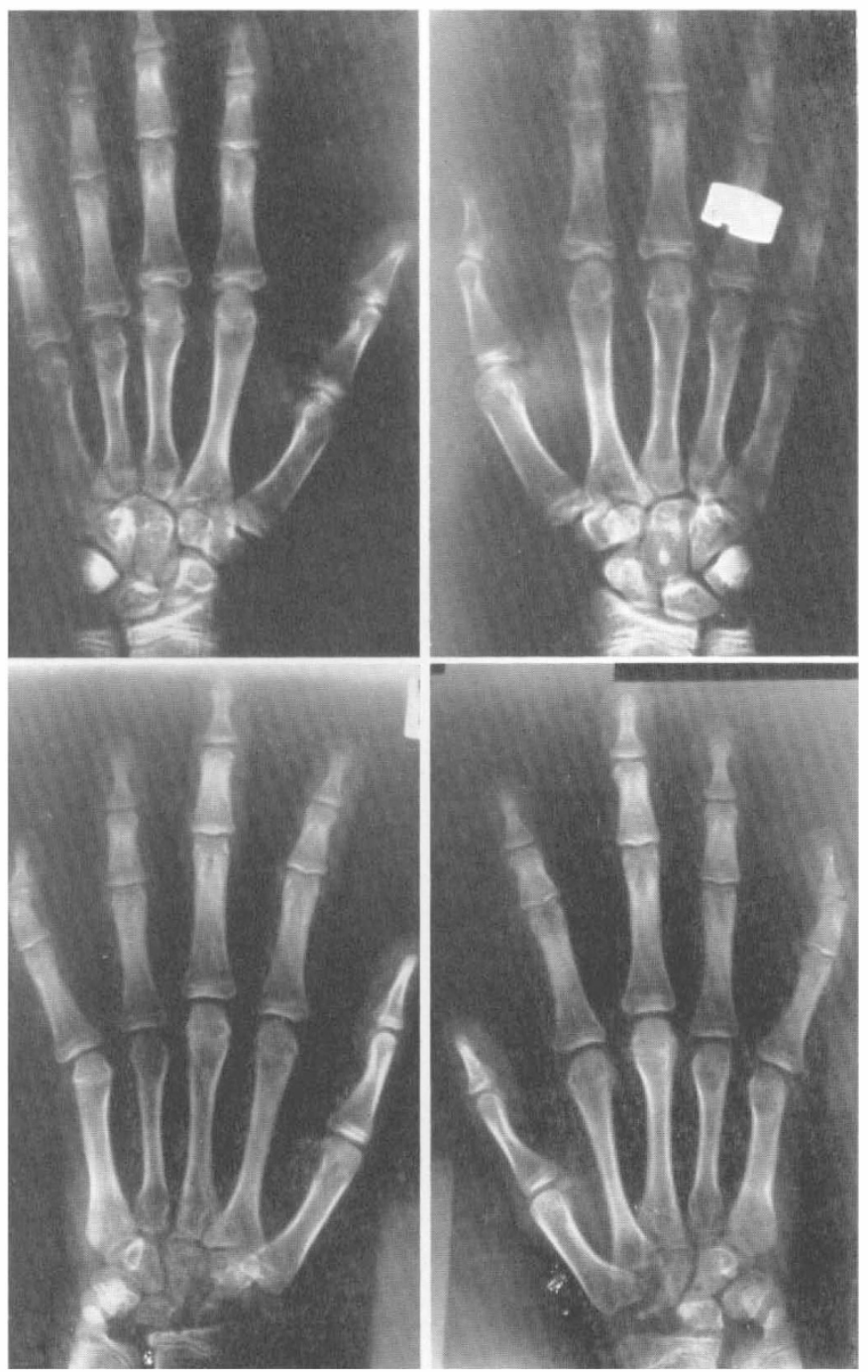

FIG. 7

Anomalies in carpal bones and lower end of radius by F. U. Normal bones S. U.

Detailed investigations of the blood groups in both twins gave identical results, i.e. Blood group $=\mathrm{A}_{1}$. Rhesus = negative. Antigens $=M N$ and SS were present. $\mathrm{F}_{\mathrm{y}}^{\mathrm{a}}$ (Duffy) was positive. $\mathrm{K}$ (Kelly) was negative.

The father's blood group is: $A_{1}$ Rhesus Negative to ant.D. Rhesus Phenotype

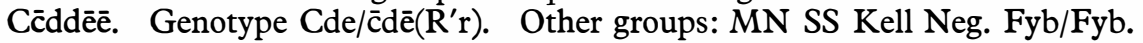


The mother's blood group is: $A_{1}$ Rhesus Positive. Rhesus Phenotype ccDēē. Probable Genotype $\bar{c} \mathrm{De} / \overline{\mathrm{c}} \mathrm{de}\left(\mathrm{R}^{\circ} \mathrm{r}\right)$. Other groups: MN Ss̄ Kell Neg. Fya Positive.

The blood group of the elder sister A. U. also suffering from the Morquio-Brailsford syndrome is A Rhesus Positive. These findings show that the two sisters A. U. and F. U. with the Morquio-Brailsford syndrome have different blood groups while the twin sisters

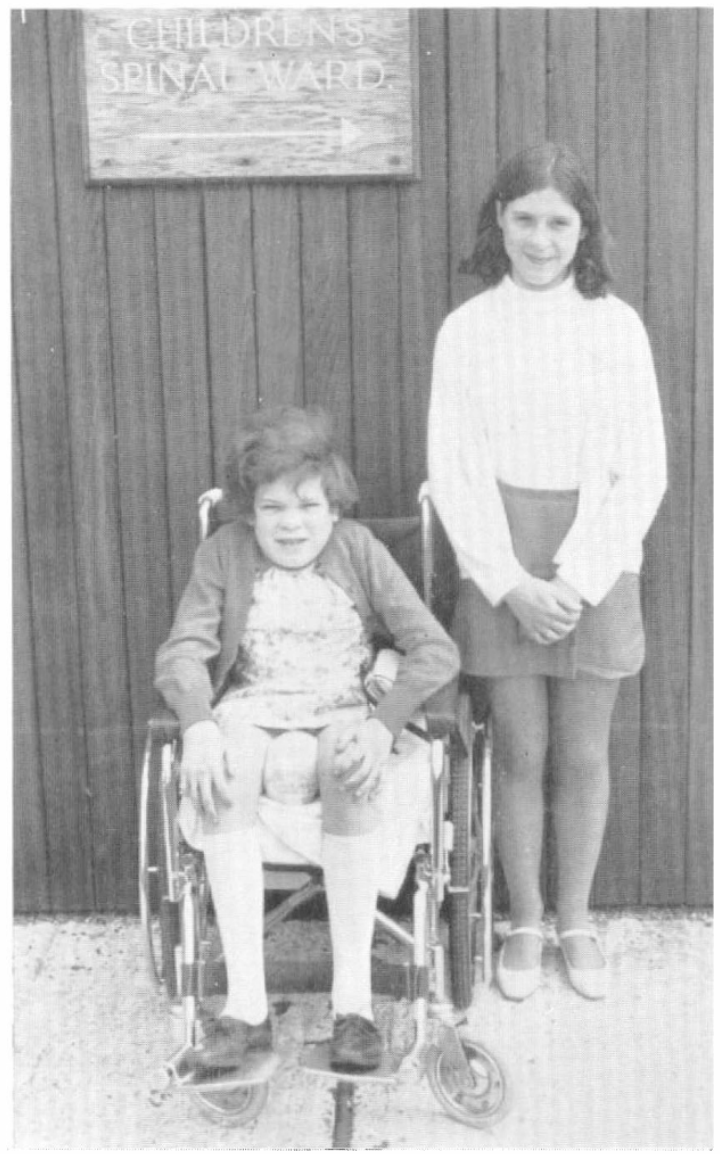

FiG. 8

The twins aged I4. F. U. is 6 inches shorter and weighs I stone $4 \mathrm{lb}$. less. Note short neck, gargoylelike face.

F. U. and S. U. have identical blood groups. Enquiries into the birth circumstances of the twins revealed that there was only one placenta. Unfortunately nothing was mentioned, if there was one or two chorionic sacs. Fingerprints investigations in the twins revealed no similarity, which apparently is absent even in uni-ovular identical twins.

All these disorders are determined by a single mutant gene in either dominant or recessive condition. Some are determined by genes on an autosomal chromosome and some by a gene on X-chromosome. In the last case the disorder is sex linked NJA A (1946). V. McKussick states that the Morquio-Brailsford syndrome 
is inherited from both parents as an autosomal recessive. It is rare and occurs I in 40,000 births.

Taking into consideration clinical symptoms, genetic factors and biochemic findings, we are able to distinguish now the following six forms of mucopolysaccharides disorders (V. McKussick, I966):

Genetic Mucopolysaccharidoses

\begin{tabular}{|c|c|c|c|}
\hline & Clinical & Genetic & Biochemical \\
\hline I. Hurler syndrome & $\begin{array}{l}\text { Early clouding of } \\
\text { cornea, serious mani- } \\
\text { festations. }\end{array}$ & $\begin{array}{l}\text { Autosomal } \\
\text { recessive }\end{array}$ & $\begin{array}{l}\text { Chondroitin Sulfate } \\
\text { B. } \\
\text { Heparitin Sulfate. }\end{array}$ \\
\hline 2. Hunter syndrome & $\begin{array}{l}\text { Cornea normal. } \\
\text { Mild course. }\end{array}$ & $\begin{array}{l}\mathrm{X} \text {-linked } \\
\text { recessive }\end{array}$ & $\begin{array}{l}\text { Chondroitin Sulf. B. } \\
\text { Heparitin Sulf. }\end{array}$ \\
\hline 3. Sanfilippo & $\begin{array}{l}\text { Mild somatic severe } \\
\text { C.N.S. changes. }\end{array}$ & $\begin{array}{l}\text { Autosomal } \\
\text { recessive }\end{array}$ & Heparitin Sulf. \\
\hline 4. Morquio-Brailsford & $\begin{array}{l}\text { Severe bony changes } \\
\text { of distinctive type, } \\
\text { cloudy cornea, intellect } \\
\text { normal or retarded, } \\
\text { aortic regurgitation. }\end{array}$ & $\begin{array}{l}\text { Autosomal } \\
\text { recessive }\end{array}$ & Keratosulfate. \\
\hline 5. Sheie & $\begin{array}{l}\text { Stiff joints, coarse face, } \\
\text { cloudy cornea, intellect } \\
\text { retarded or normal. } \\
\text { Aortic regurgitation. }\end{array}$ & $\begin{array}{l}\text { Autosomal } \\
\text { recessive }\end{array}$ & $\begin{array}{l}\text { Chondroitin } \\
\text { Sulfate B. }\end{array}$ \\
\hline 6. Maroteaux Lamy & $\begin{array}{l}\text { Severe bony changes, } \\
\text { corneal changes, } \\
\text { normal intellect. }\end{array}$ & $\begin{array}{l}\text { Autosomal } \\
\text { recessive }\end{array}$ & $\begin{array}{l}\text { Chondroitin } \\
\text { Sulfate B. }\end{array}$ \\
\hline
\end{tabular}

\section{DISCUSSION}

The Morquio-Brailsford syndrome belongs to a group of constitutional disturbances of bone growth, appearing after birth, in which the enchondral ossification is primarily impaired. The first symptoms usually appear at the time when the child starts to walk and gradually the child develops dwarfism, with short neck and trunk, kyphoscoliosis with extremities comparatively long and sometimes paraplegia.

The first case of this disorder was recognised clinically by John Thompson in Edinburgh between 1900 and I913. The first description of the clinical symptoms appeared in the Proceedings of the Royal Society of Medicine by Hunter (1917). It concerned two brothers aged Io and 8 who were dwarfs, deaf and had widely spaced teeth, short neck, hepatosplenomegaly, inguinal hernia, short, broad, thick and stiff hands, semi-flexed knees and noisy respiration. The older boy also had heart changes. 
Gertrud Hurler (I9I9) published two cases with gibbus, corneal clouding and retardation of intellect. Many cases with these clinical symptoms, with some variations, depending on the stage of advancement of the disorder, were described in the literature and various names to some symptomo-complexes attached.

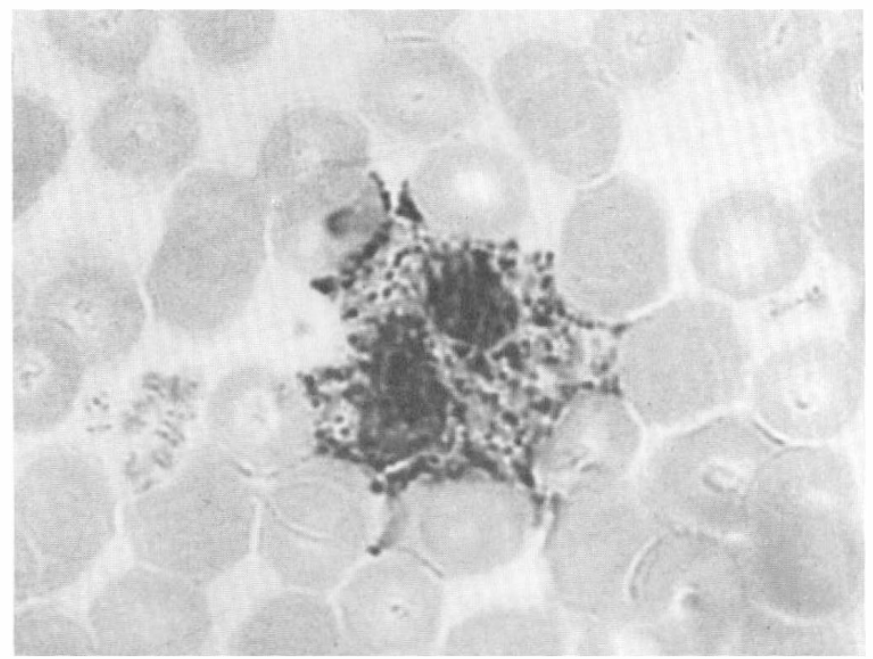

FIG. 9

Metachromatic granulations in leukocytes stained according to Muir (Toluidine blue, alcohol fixation).

FAMILY TREE

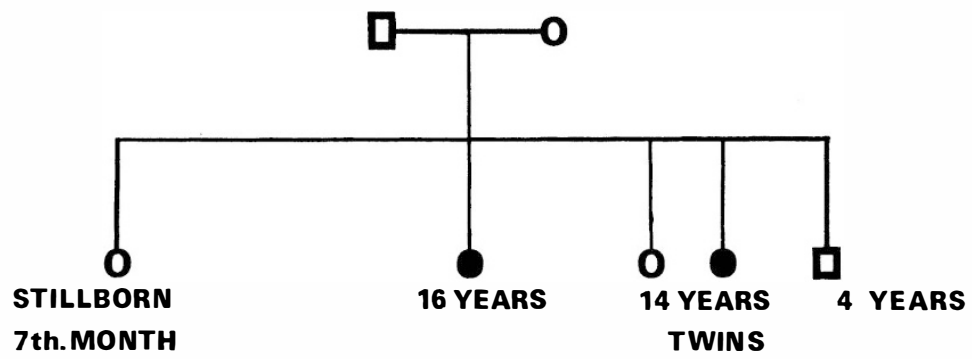

MORQUIO-BRAILSFORD SYNDROME

FIG. IO

Family tree. Healthy parents, one twin S. U. and boy aged 4. A. U. and F. U. had Morquio-Brailsford syndrome.

Dorfman and Lorincz (1957) described in Hurler syndrome presence of mucopolysaccharides in the urine. Further studies on mucopolysaccharides revealed existence of various types of these compounds: chondroitin sulfate $\mathrm{H}$., chondroitin sulfate B., Heparitin, Keratosulfate. The mucopolysaccharides are important elements of connective tissue (Uzman, 1955). 
A simple test was described by Meyer et al. (1957) when 5 per cent. solution of cetyl-tremethyl-ammonium bromide buffered to $\mathrm{pH}=6$ will reveal presence of excessive amounts of mucopolysaccharides when mixed with the urine in proportion I:5. Bartram et al. (1963) described presence of specific mucopolysaccharides in serum and urine in a case of Morquio disease.

Reilley (I94I) demonstrated presence of metachromatic granules in circulating polynuclear leucocytes and in cells in bone marrow (fig. 9). Muir (1963) described a method to demonstrate metachromatic granules in the cytoplasm of lymphocytes (toluidine blue stain after methyl alcohol fixation).

The corneal clouding, presence of granulations in the white blood cells and bone marrow, hepatosplenomegaly, and mental deterioration are considered to be the result of gluco-protein storage.

The two cases of Morquio-Brailsford syndrome described here have severe bony changes, especially in the spine, with spinal cord involvement, short neck and deformities. Both have cloudy corneae, presence of metachromatic granulations in polymorph leukocytes and their intellect is retarded. In both cases excessive amounts of mucopolysaccharides were found in the urine (Meyer's test positive). In both cases changes in the heart were found compatible with aortal valvular dysfunction. The diagnosis of Morquio-Brailsford syndrome seems the most appropriate. Further lengthy biochemical investigations are in progress in order to determine if there is a preponderance of keratosulfate in the urine which would confirm the diagnosis. The syndrome appeared here in a marriage of two healthy people with a still-born first child where the possibility that this foetus could not live because of severe constitutional changes, should be borne in mind. The next child has the Morquio-Brailsford syndrome and so has one of the twins born two years later. The fifth child, a boy, is at present developing normally with no excessive amounts of mucopolysaccharides in the urine, no corneal haziness or metachromatic granulations in the white blood cells (fig. IO).

\section{SUMMARY}

I. Two sisters with spinal deformities and paraplegia are described.

2. Apart from the original symptoms of Morquio-Brailsford syndrome the patients had the following signs:

(a) Heart changes;

(b) Positive test revealing presence of excessive amounts of mucopolysaccharides in the urine, and the following signs of 'storage syndrome';

(c) Presence of metachromatic granules in the leukocytes;

(d) Corneal clouding visible with naked eye in one case (A.V.) and with the aid of slit-lamp in the other case (F.V.);

(e) Retarded intellect.

3. The Morquio-Brailsford syndrome belongs to constitutional disorders of connective tissue when excessive amounts of mucopolysaccharides can be revealed in the urine.

\section{ACKNOWLEDGEMENT}

My thanks are due to Dr. J. J. Walsh, the Director of the National Spinal Injuries Centre, Stoke Mandeville Hospital, for encouragement and advice in publishing this paper. 


\section{REFERENCES}

Bartman, J., Mandelbaum, J. M. \& Gregoire, P. E. (1963). Rev. Franc. Etud. Clin. Biol. $8,250$.

BRAIlSFORd, J. F. (1929). Am. F. Surg. 7, 404.

Dorfman, A. \& Lorincz, A. (I957). Proc. Nat. Acad. Sci. 43, 443.

Hunter, C. (1917). Proc. R. Soc. Med. 10, I04.

HURLER, G. (I9I9). Z. Kinderheilk, 24, 220.

Maroteaux, P. \& Lamy, M. (I958). Sem. Hôp. Paris, 34, I685.

Maroteaux, P. (1967). La Medicine Infantile, 74, io.

McKussick, V. (I966). Heritable Disorders of Connective Tissue, p. 325. Saint Louis:

Meyer, K., Hoffman, P. \& Linker, A. (I957). Ann. Rheum. Dis. 16, I29.

Morquio, L. (1929). Bull. Soc. Pédiat. Paris, $27,145$.

Muir, H., Mitrwoch, V. \& Bitter, T. (1963). Archs Dis. Child., 38, 358.

NJA, A. (1946). Acta Paediat. 33, 267.

Reilley, W. A. (I94I). Am. F. Dis. Child, 62, 489.

Sanfillitio, S. J., Podosin, R., Langer, L. D. \& Good, R. A. (I963). F. Pediat. 63, 837. Sheie, H. G., Hambrick, G. W., Jr. \& Barness, L. A. (I962). Am. F. Ophthal. 53, 753. Uzman, L. L. (1955). Archs Path. 60, 308.

Zellweger, H., Giaccai, L. \& Firzli, S. (1952). Am. F. Dis. Child. 84, 42 I.

\section{ADDENDUM}

The condition of F. U. deteriorated. She developed complete loss of power and almost complete loss of sensation below $\mathrm{T}_{4}$. A myelogram showed a complete block opposite Tv and at laminectomy ( $\mathrm{Mr}$ J. Pennybacker, Oxford) spinous processes $T_{3}$ and $T_{4}$ seemed to be fibrous; there was overlapping of laminae of the upper four thoracic vertebrae causing vertical shortening, the vertebral canal was very shallow and the cord not changed. Following the laminectomy there was a remarkable improvement in power and sensation to such an extent that $F$. $U$. can now walk without calipers on crutches only. However, examination on 4 th February 1969 showed still an incomplete transverse spinal cord lesion below T4. Histological examination of the vertebral tissue showed poorly orientated cartilage columns (Dr C. G. Woods). 